\title{
MORPHEME LAND- NESTING ANALYSIS \\ ON THE BASIS OF EDUCATIONAL TEXTS
}

\author{
Kateryna Yakushko \\ Ph.D. in Pedagogy, Senior Lecturer, \\ National University of Life and Environmental Sciences of Ukraine, Ukraine \\ e-mail: vukladach@ukr.net,orcid.org/0000-0001-6977-8441 \\ Marcin Szwiec \\ Ph.D., Polonia University in Czestochowa, Interdisciplinary Faculty, Poland \\ e-mail: mszwiec@ap.edu.pl,orcid.org/0000-0002-9649-9154
}

\section{Summary}

The relevance of the article is to describe the practical experience of future land manager's linguistic investigations concerning morpheme land- nesting analysis during studying process at the Faculty of Land Management within the National University of Life and Environmental Sciences of Ukraine. The aim is either to distinguish the most common adequate word combinations to be used for own future land manager's professional conversation on the basis of morpheme land- the most frequent in use for future land manager $\mathrm{r}$ to determine the basic stages of linguistic work on English lessons. The result of the studies is the conclusion that the morpheme land- must be analyzed separately because of its wide derivations including a list of derivative compounds to have become nesting themselves.

Morpheme land-includes either 35 basic varieties (land, leased land, degradated land, sold land, purchased land, arable land, dry land, bad land, fertile land, land measuring, land natural resources, land cost definition, forest plants land, water fund land, land reconnoitre observation, land purpose, land quality, land administration, land recultivation, land cadastre, land domain, land estimation, land easement, land tax, land evaluation, land law, land melioration, land relief / terrain, land measurements, land redistribution, land surface, land of natural reserve and other nature conservation purposes, land of residential and public buildings, land of sanitary purpose). Besides, morpheme land-includes 74 additional varieties being included into 13 derivative compounds (land plan, land manager, land management, land code, land parcel, land plant, land use, land property, land samples, land probing, land crops, land owner) which have become nesting items themselves because of the regular usage for land management texts in such representation. The most nesting morpheme morpheme land- derivative compounds are land management, land plot, land parcel and land crops to be used together with 35 morpheme land- basic varieties for the future dialogue concluding on the basis of the shortened list of professional phrases. The majority of morpheme land-nesting varieties belongs either to noun-noun two components word combination or to attribute- noun two components word combinations. The majority of morpheme land-derivative compounds belong either to attribute- noun three -four component word combinations or to noun-noun three-four component word combinations. The main stages of linguistic must predict three previous stages like the stage of the land manager's adapted foreign texts reading and analysis concerning searching land- morpheme representatives, the stage of the detailed description of the nesting phenomenonand making descriptive notes and the stage of making mathematic calculations, table columns context coding and adequate statistic linguistic tables concluding. The prospect of research is to observe a range of concrete real life communicative situations on the basis of the previously distinguished common adequate morpheme land-word combinations.

Keywords: land, linguistic studies, noun-noun word combinations, attribute-noun word combinations, multistructural word combinations, morpheme, basic varieties, derivative compounds, future land manager's conversation, varieties analysis, class texts. 


\section{Introduction}

Nowadays it's important to develop soft professional skills of future engineers exampling their linguistic studies while studying foreign language at the concrete Ukrainian educational establishment. These linguistic studies must be primarily dealt with the search of common morpheme for adaptation to accept foreign terms by nesting method (Yakushko, 2020).

It is in need to distinguish lexical structure and frequency usage features of English terminological compounds with such morphemes vocabulary which is related to the most actual technical professions in the area of agriculture like specialist in agricultural automation or universal land manager (Yakushko, 2018).

The purpose of the article is to describe the practical experience of future land manager's linguistic investigations concerning morpheme land-nesting analysis during studying process at the Faculty of Land Management within the National University of Life and Environmental Sciences of Ukraine in Kyiv during the second semester of 2019/2020 curriculum period. The aim is to distinguish the most common adequate word combinations to be used for own future land manager's professional conversation on the basis of morpheme land-as the most frequent in use for future land manager (Yakushko, 2020). Besides, it's important to regard it either as free or a bound type of morpheme (Independent learning platform, 2020).

The main methods of the conducted research were the students' linguistic analysis of the educational texts concerning searching land- morpheme representatives, making descriptive notes, making mathematic calculations, table columns context coding and adequate statistic linguistic tables concluding.

\section{The stage of the land manager's adapted foreign texts reading and analysis concerning searching land- morpheme varieties representatives}

On this stage the students have work with the seven adapted educational texts from the adequate textbook concerning the topics on geodesy, cadastre, GIS, mapping, soil studying etc. (Yakushko, 2020) exampling following item of text being related to the land management in general:

Land Management is a universal specialty dealing engineering, economy, chemistry, agriculture, geography automation etc. A land manager deals with land law, land use, geodesy, land cadastre, land administration, land measurements like land parcel boundaries, land planning environmental economics for all land parcels and land plots. Landowners and land users need him as land manager, surveyor or land planner for land management or land planning works, land-use planning surveying works taking into account ecological network state. In general, land management is the branch of agriculture dealing with land reforms as well as cadastre and distribution of land natural resources. Planning crop rotation is one of the main tasks for both agronomists and land managers.

A land manager can not do without Math calculations too. He deals with arithmetic operations for some uneven or homogeneous points measurements. A land manager may use calibrated tube or ruler to multiply length and width while measuring square area of land parcel with accuracy. Besides, he can divide, subtract or add the value of height, depth or length numbers while geodetic objects inventory. A land manager must be able to calculate increasing ratio values of land taxes for every leased land parcel area without any measurement error.

Professional training at our Land Management Faculty being guided by Taras O. Yevsiukov within the National University of Life and Environmental Sciences of Ukraine is provided by 5 following special departments: a) Management of Land Resources; b) Land Cadastre; c) Land 
Use Planning; d) Geodesy and Cartography; e) Geoinformatics and Aerospace Research of the Earth. Their activity is devoted to land relations, land management, land planning and development projects and the state of land cadastre, planning environmental protection, monitoring and governmental control of rational land use, protection of land etc. Thus, the future land managers study on 5 following programs: a) land management and cadastre; b) land conservation; c) evaluation of land and real estate; d) geodesic-cartographic technologies in land management; e) GIS in land management.

All subjects studied at the University are very important. Land-survey studies land estimation; land law and geology deal with the structure of the land. The experts in geodesy and cartography will carry out aerial shootings of the earth and make maps. Geoinformation system will help to make the programs for drawing up of maps and estimations. Our students have practice in subdivisions of the State Committee for Land Resources of Ukraine, the Central and regional research and project institutes of Land Management, State Land Cadastre Centre, Institute of Agricultural Surveys, etc. The faculty cooperates with land management foreign institutions like Italy, USA, Germany etc. too.

Even this one adapted educational text gave variants background for further analyzing because of such thirty three morpheme land- varieties as land manager, land law, land use, land cadastre, land administration, land measurements, land parcel boundaries, land planning environmental economics, land parcels, land plots, landowners, land user, land planner, land management, land planning works, land-use planning surveying works, land reforms, land natural resources, land taxes, land parcel area, Land Management Faculty, Management of Land Resources, Land Use Planning; land relations, land management, land planning and development projects, state of land cadastre, protection of land, land conservation; evaluation of land land-survey studies, land estimation; the State Committee for Land Resources of Ukraine, State Land Cadastre Centre, etc.

\section{The stage the detailed description of the nesting phenomenonand making descriptive notes}

On this stage the students have investigated that morpheme land- is mainly nested in more than one hundred varieties exampling thirty five basic varieties and seventy four additional varieties.

Morpheme land- is mainly represented in following thirty five basic varieties: nine attribute-noun two components word combination (leased land, degradated land, sold land, purchased land, arable land, dry land, bad lad, fertile land, land measuring), oneattribute-noun three components word combinations (land natural resources), two noun-noun three components word combinations (land cost definition, forest plants land, water fund land, land reconnoitre observation), sixteen two components noun-noun word combinations (land purpose, land quality, land administration, land recultivation, land cadastre, land domain, land estimation, land easement, land tax, land evaluation, land law, land melioration, land relief / terrain), land measurements, land redistribution, land surface), three multistructural word combinations with of (land of natural reserve and other nature conservation purposes, land of residential and public buildings, land of sanitary purpose).

Morpheme land- is mainly represented in following thirteen additional derivative varieties:

a) land plan- as derivative compound in three varieties to become nesting itself: two noun-noun two components word combinations (land planner, land planning) and one nounnoun three component word combination (land planning object);

b) land manager- as derivative compound in four varieties to become nesting itself: one nesting item (land manager), two noun-noun three components word combinations (land 
manager's experience, land manager's studying) and one noun- attribute four component word combinations (land manager's practical skills);

c) land management- as derivative compound in seven varieties to become nesting itself: one nesting item (land management), six three components word combinations (Land Management Faculty, land management documentation, land management works, land management science, land management departments, land management chairs);

d) land code- as derivative compound in three varieties to become nesting itself: one nesting item (land code), two noun-noun three components word combinations (land code article, Ukraine's Land Code (LCU));

e) land plot- as derivative compound in nine varieties to become nesting itself: one nesting item (land plot), five noun-noun three components word combinations (land plot evaluation, land plot map, land plot cost, land plot painuing, land plot boundary), one three components word combination with of (positioning of land plot), three attribute-noun two components word combinations (own land plot, state land plot, neighbouring land plot).

f) land parcel- as derivative compound in seven varieties to become nesting itself: one nesting item (land parcel), five noun-noun three components word combinations (parcel evaluation, land parcel map, land parcel cost, land parcel painuing, land parcel boundary), one three components word combination with of (positioning of land parcel), three attribute-noun two components word combinations (own land parcel, state land parcel, neighbouring land parcel).

g) land plant- as derivative compound in four varieties to become nesting itself: one nesting item (land plant), two three components noun-noun word combinations (land plants cover, land plants protection), one four components word combinations (land plants crop rotation).

h) land use- as derivative compound in five varieties to become nesting itself: one nesting item (land use), one two components word combination (land user), two three components word combinations (land use relations, farm use land), one four components word combination (recreational resort use lands);

i) land property- as derivative compound in three varieties to become nesting itself: one nesting item (land property), two three components noun-noun word combinations (land real property, land property ownership);

g) land samples-as derivative compound in three varieties to become nesting itself: one nesting item (land samples), two three components word combinations (land samples analysis, land samples/ definition);

k) land probing-as derivative compound in three varieties to become nesting itself: one nesting item (land probing), two three components word combinations (land probing analysis, land probing definition);

1) land crops- as derivative compound in three varieties to become nesting itself: one nesting item (land crops), five three components word combinations (land crops cover, land crops rotation, land crops growth, land crops planning, land crops inventory).

$\mathrm{m})$ land owner- as derivative compound in three varieties to become nesting itself: one nesting item (land owner), one two components word combination (land ownership).

\section{The stage of making mathematic calculations, table columns context coding and adequate statistic linguistic tables concluding}

On this stage the research results were visually represented in two tables after the following coding of their both context columns:

A- the title of morpheme;

$\mathrm{B}$ - the total number of varieties;

$\mathrm{C}$ - the number of nesting items; 
D- the number of separate noun in one word;

E- the number of separate attribute in one word;

F- the number of multistructural word combinations with of;

$\mathrm{G}-$ the number of noun-noun two components word combination;

I- the number of attribute- noun two components word combinations;

$\mathrm{J}$ - the number of attribute- noun three -four component word combinations

$\mathrm{K}$ - the number of noun- noun three-four component word combinations.

Table 1. Morpheme land-nesting analysis result in basic varieties

\begin{tabular}{|c|c|c|c|c|c|c|c|c|c|}
\hline $\mathrm{A}$ & B & $\mathrm{C}$ & $\mathrm{D}$ & $\mathrm{E}$ & $\mathrm{F}$ & $\mathrm{G}$ & I & $\mathrm{J}$ & $\mathrm{K}$ \\
\hline $\begin{array}{l}\text { land, leased land, degradated land, sold } \\
\text { land, purchased land, arable land, dry land, } \\
\text { bad lad, fertile land, land measuring, land } \\
\text { natural resources, land cost definition, forest } \\
\text { plants land, water fund land, land reconnoi- } \\
\text { tre observation, land purpose, land quality, } \\
\text { land administration, land recultivation, land } \\
\text { cadastre, land domain, land estimation, land } \\
\text { easement, land tax, land evaluation, land law, } \\
\text { land melioration, land relief / terrain), land } \\
\text { measurements, land redistribution, land sur- } \\
\text { face), land of natural reserve and other nature } \\
\text { conservation purposes, land of residential and } \\
\text { public buildings, land of sanitary purpose. }\end{array}$ & 35 & 1 & 1 & 0 & 3 & 17 & 9 & 1 & 4 \\
\hline
\end{tabular}

Table 2. Morpheme land-nesting analysis result in derivative compounds

\begin{tabular}{|l|l|l|l|l|l|l|l|l|l|}
\hline \multicolumn{1}{|c|}{$\mathbf{A}$} & $\mathbf{B}$ & $\mathbf{C}$ & $\mathbf{D}$ & $\mathbf{E}$ & $\mathbf{F}$ & $\mathbf{G}$ & $\mathbf{I}$ & $\mathbf{J}$ & \multicolumn{1}{|c|}{$\mathbf{K}$} \\
\hline land plan & $\mathbf{4}$ & 1 & 2 & 0 & 0 & 0 & 0 & 0 & 1 \\
\hline land manager & $\mathbf{4}$ & 1 & 0 & 0 & 0 & 0 & 0 & 1 & 2 \\
\hline land management & $\mathbf{7}$ & 1 & 0 & 0 & 0 & 0 & 0 & 6 & 0 \\
\hline land code & $\mathbf{3}$ & 1 & 0 & 0 & 0 & 0 & 0 & 2 & 0 \\
\hline land plot & $\mathbf{1 3}$ & 1 & 0 & 0 & 1 & 0 & 3 & 5 & 3 \\
\hline land parcel & $\mathbf{1 3}$ & 1 & 0 & 0 & 1 & 0 & 3 & 5 & 3 \\
\hline land plant & $\mathbf{4}$ & 1 & 0 & 0 & 0 & 0 & 0 & 0 & 3 \\
\hline land use & $\mathbf{6}$ & 1 & 0 & 0 & 0 & 1 & 0 & 1 & 3 \\
\hline land property & $\mathbf{3}$ & 1 & 0 & 0 & 0 & 0 & 0 & 1 & 1 \\
\hline land samples & $\mathbf{4}$ & 1 & 0 & 0 & 0 & 0 & 0 & 1 & 2 \\
\hline land probing & $\mathbf{4}$ & 1 & 0 & 0 & 0 & 0 & 0 & 1 & 2 \\
\hline land crops & $\mathbf{6}$ & 1 & 0 & 0 & 0 & 0 & 0 & 1 & 5 \\
\hline land owner & $\mathbf{3}$ & 1 & 0 & 0 & 0 & 2 & 0 & 0 & 0 \\
\hline Total amount & $\mathbf{7 4}$ & $\mathbf{1 3}$ & $\mathbf{2}$ & $\mathbf{0}$ & $\mathbf{2}$ & $\mathbf{3}$ & 6 & 24 & 25 \\
\hline
\end{tabular}

\section{Conclusions}

The conclusions may be represented in a eight points list sample:

1. Morpheme land- must be always analyzed separately from other adequate land management texts morphemes because of its wide derivations including a list of derivative compounds to have become nesting themselves. 
2. Morpheme land- includes 35 basic nesting representatives (land, leased land, degradated land, sold land, purchased land, arable land, dry land, bad land, fertile land, land measuring, land natural resources, land cost definition, forest plants land, water fund land, land reconnoitre observation, land purpose, land quality, land administration, land recultivation, land cadastre, land domain, land estimation, land easement, land tax, land evaluation, land law, land melioration, land relief / terrain, land measurements, land redistribution, land surface, land of natural reserve and other nature conservation purposes, land of residential and public buildings, land of sanitary purpose).

3. Morpheme land-includes 74 additional varieties being included into 13 derivative compounds(land plan, land manager, land management, land code, land parcel, land plant, land use, land property, land samples, land probing, land crops, land owner) which have become nesting items themselves because of the regular usage for land management texts in such representation.

4. The most nesting morpheme land-derivative compounds are land management, land plot, land parcel and land crops to be used together with 35morpheme land-basic varieties for the future dialogue concluding on the basis of the shortened list of professional phrases.

5. The majority of morpheme land- nesting varieties belongs either to noun-noun two components word combination or to attribute- noun two components word combinations.

6. The majority of morpheme land-derivative compounds belong either to attributenoun three -four component word combinations or to noun-noun three-four component word combinations.

7. The main stages of linguistic must predict three previous stages like the stage of the land manager's adapted foreign texts reading and linguistic analysis concerning searching landmorpheme representatives, the stage of the detailed description of the nesting phenomenonand making descriptive notes and the stage of making mathematic calculations, table columns context coding and adequate statistic linguistic tables concluding.

8. The prospect of research is to observe a range of concrete real life communicative situations on the basis of the previously distinguished common adequate morpheme land- word combinations.

\section{References}

Independent learning platform (2020). Free Morphemes and Bound Morphemes. URL: https://vlearn.fed.cuhk.edu.hk/wordformation/internalstructure/freemorphemes/

Yakushko, K.H. (2019). Anglijska mova dlia pidhotovky fakhivtsiv OS "Bakhalavr” zi spetsialnosti "Geodeziya ta zemleustrij”" [English for Geodesy]. Kyiv: Ekspo-Druk [in Ukrainian]. Yakushko, K.H. (2020). Anglomovni vidpovidnyky osnovnykh morfem terminiv zemlevporiadkuvannia / Tavrijki fililihichni naukovi chytannia: materialy mizhnarodnoji naukovo-praktychnoji konferentsiji 24-25 sichnia 2020 r Ch.2. [English equivalents to the land management basic morphemes/Tavrida philological meetings: materials of the international January 24-25 2020 scientific conference P. 2]. Kyiv: Helvetyka [in Ukrainian].

Yakushko, K.H. (2020). The categories of specialized vocabulary in the sphere of automation to develop students'foreign language communicative skills/ Modern researches in philological sciences: collective monograph. Romania: Baia Mare.

Yakushko, K.H. (2018). Osoblyvosti leksychnoho skladu ta chastotnosti vzhyvannia aanhliiskykh terminolohichnykh spoluk z morfemoyu aut-/ Molodyi vchenyi №7(59) [Lexical structure and frequency usage features of English terminological compounds with morpheme aut]. Kherson: Young scientist [in Ukrainian]. 